\title{
Design, Synthesis and Biological Evaluation of Novel Analogs of Bortezomib
}

\author{
R. Janaki Rama Rao, A. K. S. Bhujanga Rao*, K. Swapna, B. Baby Rani, S. Prasanna Kumar \\ S. Awantika, and Y. L. N. Murthy ${ }^{\dagger}$ \\ Natco Research Centre, Natco Pharma Ltd., Hyderabad, Andhra Pradesh, PIN. 500018, India. \\ *E-mail: nrc@natcopharma.co.in \\ ${ }^{\dagger}$ Department of Organic Chemistry, Andhra University, Visakhapatnam, Andhra, Pradesh, PIN. 530003, India
}

(Received March 25, 2011; Accepted July 8, 2011)

\begin{abstract}
Novel analogs of bortezomib were designed, synthesized and in vitro biological evaluation was carried out using human tumor cell lines A549 and PC3. Docking studies of these analogs of bortezomib was discussed. According to biological investigations, the inhibitors 4,6 , and 8 were found to be more potent than reference drug candidate bortezomib. A549 cell line showed significant sensitivity towards 4 , 6 , and 8 with $\mathrm{IC}_{50}$ values $14.03,18.5$, and $12.4 \mathrm{nM}$, respectively, and PC3 cell line showed $\mathrm{IC}_{50}$ values $26.1,37.0$, and $21.2 \mathrm{nM}$, respectively. The $\mathrm{IC}_{50}$ values of bortezomib in these cell lines are $27.3 \mathrm{nM}$ and $42.0 \mathrm{nM}$.
\end{abstract}

Key words: Bortezomib, human tumor cell lines, A549, PC3, $\mathrm{IC}_{50}$ values

\section{INTRODUCTION}

The ubiquitin-proteasome pathway (UPP) plays an essential role in the maintenance of homeostasis in cells and organisms and it is responsible for the degradation of more than $80 \%$ normal and abnormal intracellular proteins. ${ }^{1}$ The proteasome $26 \mathrm{~S}$ complex is a large multiprotein complex with a molecular weight of $700 \mathrm{kDa}$ present in both the cytoplasm and the nucleolus of all eukaryotic cells. ${ }^{2}$ It is composed of two functional components, a $20 \mathrm{~S}$ core catalytic complex and the $19 \mathrm{~S}$ regulatory subunit. The $26 \mathrm{~S}$ proteasome plays an essential role in the UPP by acting as the final proteolytic effect or of cellular proteins targeted by polyubiquitination for destruction. The realization that the proteasome is so critically related to the development of a number of major human diseases promoted research into the design and the synthesis of various proteasome inhibitors and the evaluation of their therapeutic potentials. In recent years, there has been a great deal of interest in proteasome inhibitors as novel class of anticancer candidates and some of them entered clinical trials such as bortezomib. ${ }^{3}$

Bortezomib is a dipeptide boronic acid proteasome inhibitor. It effects the degradation of polyubiquitinated proteins destined for catalysis by the proteasome. The boronic acid moiety of bortezomib is thought to form a stable tetrahedral complex with the active site N-terminal threonine residue of the 20S $\beta 5$ subunit. Bortezomib is very efficacious and more potent among the drugs used for treatment of multiple myeloma, invented by Millennium pharmaceuticals USA. Bortezomib was approved by the FDA for the treatment of patients with relapsed and refractory multiple myeloma (MM) approved in 2003 with at least one prior line therapy and for the treatment of mantle cell lymphoma (MCL, approved in 2006). ${ }^{4,5}$

Multiple myeloma is a bone marrow cancer generally thought to be incurable, but remission may be induced with chemotherapy and stem cell transplants. It occurs more commonly in men. There are approximately 20,000 new cases of myeloma in the U.S. each year. At any time there are over 100,000 myeloma patients undergoing treatment for their disease in the U.S. Bortezomib shows significant antitumor activity in human tumor xenograft models. Experiments have demonstrated that bortezomib is cytotoxic to a variety of cancer cell types in vitro. Bortezomib causes a delay in tumor growth in vivo in non-clinical tumor models, including multiple myeloma.

The chemical name of bortezomib is [(1R)-3-methyl-1[[(2S)-1-oxo-3-phenyl-2-[(Pyrazinylcarbonyl)amino]propyl]-amino]butyl] boronic acid and its chemical structure is given below(Fig. 1). Bortezomib is marked under the brand name Velcade ${ }^{\circledR}$ (intravenous injection).

Some interesting analogs of bortezomib were reported in recent literature. Yongqiang and coworkers, ${ }^{6}$ synthesized and evaluated biological study of the some novel analogs of bortezomib. The general structure is depicted in Fig. 2. 
<smiles>CC(C)C[C@H](NC(=O)C(Cc1ccccc1)NC(=O)c1cnccn1)B(O)O</smiles>

Fig. 1. Bortezomib.<smiles>[2H]C[C@H](NC(=O)[C@H](CP)NC(=O)P)B1OC(C)(C)OC1(F)F</smiles>

$\mathrm{P}_{1}=1,2,3,4$-tetrahydronaphthyl, 5,6,7,8-tetrahydronaphthyl, methyl, tertbutoxy, and benzyloxy etc;

$\mathrm{P}_{2}=$ methyl, naphthyl, 4-hydroxyphenyl, and indole, etc;

$\mathrm{P}_{3}=$ tolyl, 4-fluorophenyl, and phenyl etc;

$\mathrm{P}_{4}=$ pinanediol and $\mathrm{H}$

Fig. 2. Novel analogs of Bortezomib.

Among the above compounds, the analogues where the 2-pyrazinyl moiety of bortezomib is replaced with 1,2,3,4tetrahydronaphthyl and 5,6,7,8-tetrahydronaphthyl showed higher inhibitory activity against solid tumors.

The same authors also synthesized, and studied in vitro and in vivo biological activity of dipeptidyl boronic acid proteasome inhibitors composed of $\beta$ amino acids ${ }^{7}$. The general structure of these compounds is depicted in Fig. 3.

The synthesis and biological evaluation of tripeptide boronic acids as proteasome inhibitors has been reported ${ }^{8}$. 2-Pyrazinyl and L-leucinyl moieties of bortezomib are kept intact in this series of tripeptide boronic acids. In between 2-pyrazinyl and L-leucinyl moieties of bortezomib two different kinds of $\alpha$-amino acids were intro-<smiles>[R3]CC(NC(=O)CC(NC([R1])=O)c1ccc([R2])cc1)B(O)O</smiles>

$\mathrm{R} 1=\mathrm{Pyz}, \mathrm{Ph}$, nicotin-3-yl, THNA

$\mathrm{R} 2=\mathrm{H}, \mathrm{CH}_{3}, \mathrm{OCH}_{3}, \mathrm{Cl}$

$\mathrm{R} 3=\mathrm{Pr}, \mathrm{Ph},\left(4-\mathrm{CH}_{3}\right)-\mathrm{Ph}$

Fig. 3. General structure of dipeptidylboronic acids containing $\beta$-amino acids.<smiles>CC(C)C[C@H](NC(=O)[C@H](CP)NC(=O)[C@H](CP)NC(=O)c1cnccn1)B1OC(C)(C)PC1(C)C</smiles>

$\mathrm{P}_{2}=$ L-tyrosine, L-leucine, L-phenylalanine, L-(2-naphthyl)alanine, and L-tryptophan

$\mathrm{P}_{3}=$ L-phenylalanine, L-(2-naphthyl)alanine, L-tryptophan $\mathrm{P}_{4}=$ pinanediol, $\mathrm{H}$

Fig. 4. General structure of tripeptideboronic acids.

duced by peptide bond formation.General structure of tripeptideboronic acids shown in Fig. 4.

A review of literature indicated that attempts were made to replace 2-pyrazinyl moiety with phenyl, tetrahydronaphthyl, methyl and tert-butoxy components. ${ }^{6-8}$ No heterocyclic moiety was introduced for the replacement of 2-pyrazinyl fragment of bortezomib.

As the heterocyclic fragments play a vital role in biological activities of many pharmaceutical ingredients, we aimed to synthesize novel analogs of bortezomib by replacing the 2-pyrazinyl moiety with other heterocyclic ring systems and to study the biological activity of these analogs in vitro on human cell lines.

In this manuscript, we described the design, docking studies, synthesis, and in vitro cytotoxicity evaluation with human tumor cell lines A549 (lung cancer) and PC3 (prostate cancer) of novel analogs of bortezomib as potential anticancer agents.

\section{RESULTS AND DISCUSSION}

\section{Molecular docking studies}

We performed docking studies to screen the designed analogs of bortezomib. To date, several ligand-proteasome crystal complexes have been reported. ${ }^{9-12} \mathrm{We}$ selected Cocrystal structure of 20S proteasome in complex with bortezomib for our studies. Cocrystal structures (PDB ID-2F16) demonstrate that protein consist of 28 chain. The docking process was carried out by Discovery Studio C-Docker program. The docking results offered useful information for understanding the interaction mode and potency of molecules. The protein and ligands for docking were prepared using software Discovery Studio2.5. The initial structure was derived from the crystal complex coordinates (PDB code-2F16). A set of ligand conformations were generated using high temperature molecular dynamics with random seed. For each final pose, 
CHARMm energy and interaction energy were calculated. First to test credibility of the developed docking procedure, the structure of bortezomib was docked into the binding pocket. As shown in the docking result, designed 10 analogs were docked in same binding site, by using above mentioned docking procedure.

\section{Docking results}

The structural formulas and docking results of novel analogs of bortezomib of present work are mentioned in Table 1.

The above results revealed that out of ten docked analogs six compounds $3,4,5,6,8$, and 9 are good and in turn $\mathbf{8}$ is more potent among them. Molecules $\mathbf{7}$ and $\mathbf{1 0}$ have been predicted to have moderate activity and molecule $\mathbf{1}$ and $\mathbf{2}$ are expected to be least active. In the above ten ana-

Table 1. Docking studies of bortezomib and its analogs

Molecule

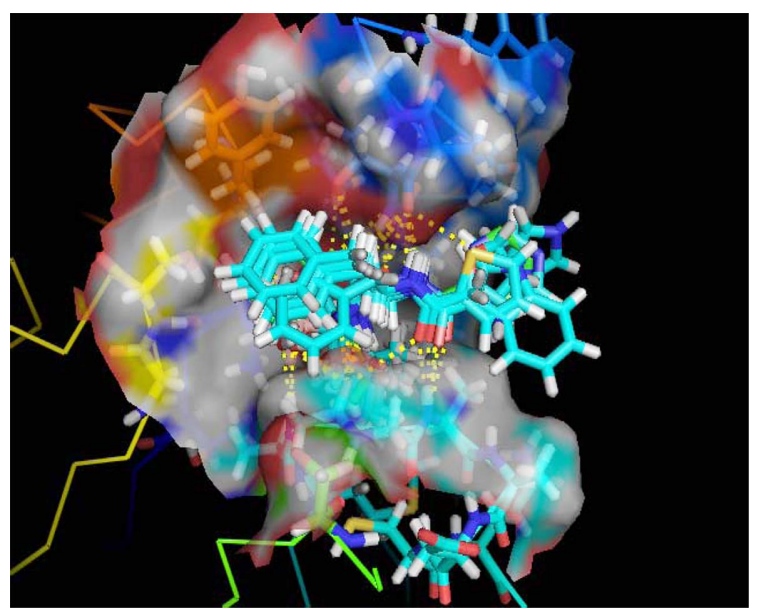

Fig. 5. Binding Sites of analogs $3,4,5,6,8$, and 9 with reference bortezomib (green) in binding site of protein.

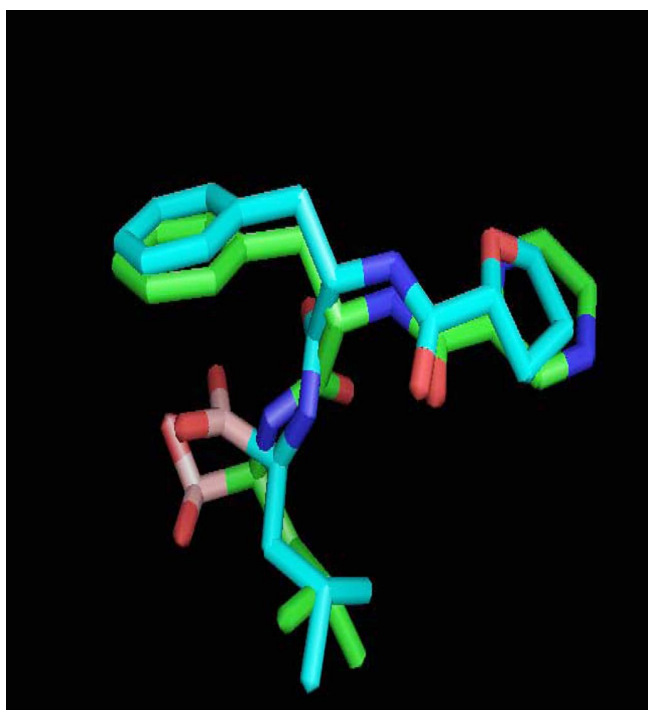

Fig. 6. Superimposition of analog 8 with reference molecule (green color).

logs we aimed to synthesize three more active $(4,6,8)$ and two least active compounds $(\mathbf{1}, \mathbf{2})$ to study biological activity using A549 and PC3 cell lines.

The alignment of novel analogues 3, 4, 5, 6, 8, and 9 with bortezomib (green) in binding site of protein is showed in Fig. 5. Superimposition of analog $\mathbf{8}$ with reference molecule bortezomib (green color) is depicted in Fig. 6. Hydrogen bonding and binding affinity of more potent analog 8 are depicted in Fig. 7 and Fig. 8 respectively.

\section{Chemistry}

The analogs of bortezomib studied involve introduction of 5- and 6-membered ring heterocyclic moieties in 


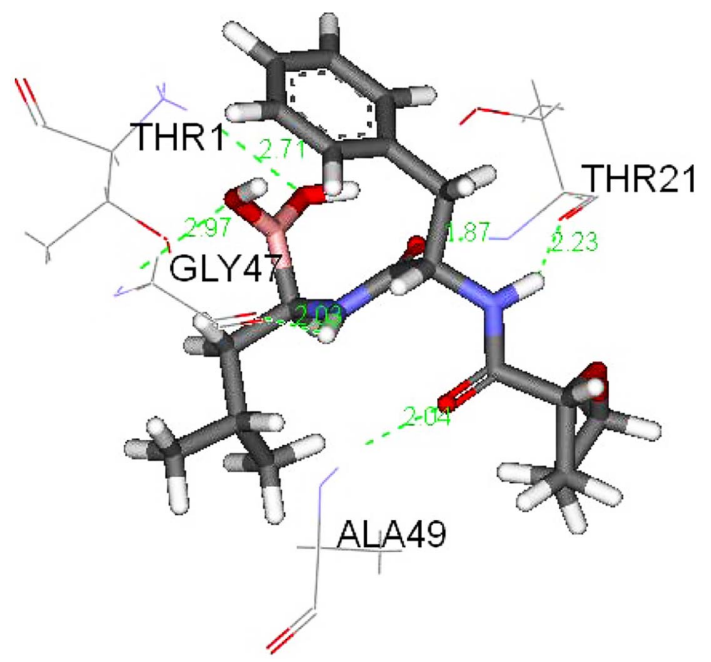

Fig. 7. H-bonds of analog 8.

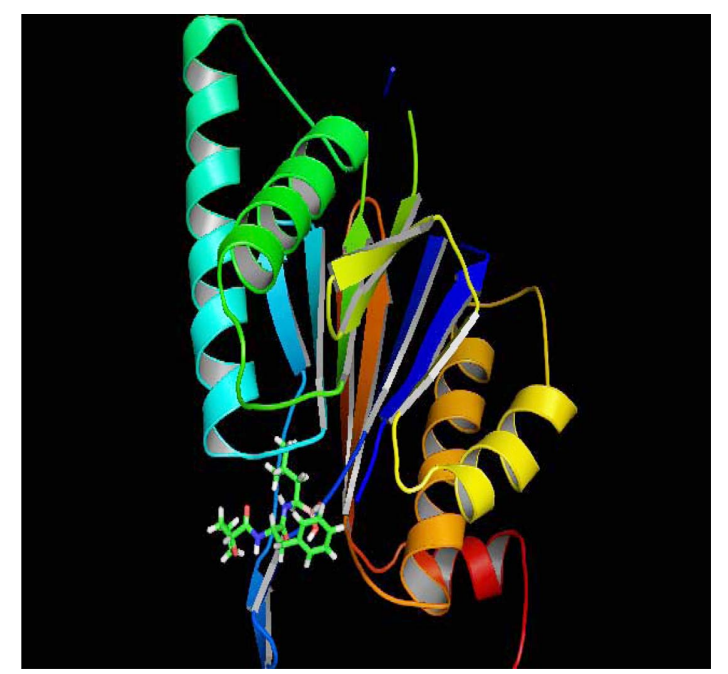

Fig. 8. Analog 8 with protein.

place of 2-pyrazinyl moiety. Ten novel analogues of bortezomib were designed by replacing 2-pyazinyl moiety of bortezomib with 2-thiophene, 3-thiophene, 2-tetrahydrofuran, proline, histidine, 4-nicotinyl, isonipecotyl, indole, tryptophan and isoquinoline residues. As indicated by docking studies compounds with 4-nicotinyl, 2-thienyl, 2tetrahydrofuryl fragments $(\mathbf{4 , 6}$ and $\mathbf{8})$ are more potent and compounds with tryptophan, proline $(\mathbf{1}, \mathbf{2})$ are least active, the remaining analogs being moderately active.

Synthesis of analogs 4, 6, 8 of bortezomib involves coupling of $(1 R)-(1 S, 2 S, 3 R, 5 S)$-pinanediol leucine boronate trifluoroacetate salt (11) ${ }^{13}$ with N-BOC- $\beta$-(1-phenyl)-L-alanine (12) in the presence of TBTU to yield $(1 S, 2 S, 3 R, 5 S)$ pinanediol-N-BOC- $\beta$-(1-phenyl)-L-alanine-L-leucine boronate (13). The resulting compound was treated with
EtOAc- $\mathrm{HCl}$ to yield BOC deprotected compound $(1 S, 2 S$, $3 R, 5 S)$-pinanediol- $\beta$-(1-phenyl)-L-alanine-L-leucine boronate $\mathrm{HCl}(14)$ and was coupled with the corresponding carboxylic acid in the presence of TBTU to get dipeptidyl compound (15). Finally pinanediol moiety of above dipeptidyl compound (15) was deprotected with isobutyl boronic acid to afford corresponding dipeptidyl boronic acids 4, 6, and $\mathbf{8}$ (Scheme 1). The products were obtained in moderate yields with $>98 \%$ purity (HPLC).

In case of preparation of analogs 1 and 2 the corresponding Boc protected amino acids (16) have been employed to react with $(1 S, 2 S, 3 R, 5 S)$-pinanediol- $\beta$ - $(1$ phenyl)-L-alanine-L-leucine boronate $\mathrm{HCl}(14)$ to get compound 17 . The BOC moiety of amino acid was deprotected with 1,4-dioxane-HCl to yield BOC-deprotected dipeptidyl boronate (18) and the resulting compound was treated with isobutyl boronic acid to get required bortezomib analogs $\mathbf{1}$ and $\mathbf{2}$ (Scheme 2).

The starting material $(1 R)-(1 S, 2 S, 3 R, 5 S)$-pinanediol leucine boronate trifluoroacetate salt (11) was prepared by homologation of $(1 S, 2 S, 3 R, 5 S)$-pinanediol isobutyl boronate (19) using dichloromethane as reagent in the presence of a strong base like LDA (lithium diisopropylamide, prepared insitu by reacting $n$-BuLi and diisopropylamine) followed by Lewis acid catalysis. The Lewis acid used was zinc chloride that catalyses the rearrangement of intermediate dichloromethylboronate complex to get $(1 S)$ (S)-pinanediol-1-chloro-3-methylbutane-1-boronate (20). The reaction requires subzero temperatures $\left(-60\right.$ to $\left.-70{ }^{\circ} \mathrm{C}\right)$. The resulting homologated product (20) was reacted with lithium bis(trimethylsilyl)amide at $-20^{\circ} \mathrm{C}$ to yield $(1 R)$ (S)-pinanediol-1-bis(trimethylsilyl)amino-3-methylbutane1-boronate (21). The disilazane compound obtained was treated with trifluoroacetic acid at $0{ }^{\circ} \mathrm{C}$ to afford the required starting material $(1 R)-(1 S, 2 S, 3 R, 5 S)$-pinanediolleucineboronatetrifluoroacetate salt (11) (Scheme 3).

\section{Biological activity}

Bortezomib and its analogs 1, 2, 4, 6, and 8 were dissolved in DMSO as a $10 \mathrm{mM}$ stock solution and diluted to required concentration with PBS (1X) (Phosphate Buffer Saline). Cytotoxicity analysis was carried out by using 3(4,5-dimethylthiazol-2-yl)2,5-diphenyl- tetrazolium bromide (MTT) dye reduction assay. The MTT kit received from promega and procedure followed by therein instructed. Exponential growing cells were exposed to bortezomib and $1,2,4,6$, and 8 for the indicated time. The drug induced cytotoxicity was assessed by the MTT assay. Lung cancer cell line and prostate cancer cell line (A549 
<smiles>CC(C)C[C@H](N)B1OC2CC3CC(C2(C)C)C1(C)C3(C)C</smiles>

11<smiles>CCOC(=O)C1CC2CCC1(C)C(C)(C)OB2CC(C)C</smiles>
R-COOH, TBTU, $0-3^{\circ} \mathrm{C}, \mathrm{CH}_{2} \mathrm{Cl}_{2}$ isobutyl boronic acid

aq. $\mathrm{HCl}, \mathrm{RT}$ methanol, n-heptane
$\mathrm{N}, \mathrm{N}$-diisopropyl ethyl amine

$\underset{\mathrm{N}, \mathrm{N} \text {-diisopropyl ethyl amine }}{\stackrel{\mathrm{TBTU}}{0} 0 \text { to } 3^{\circ} \mathrm{C}, \mathrm{CH}_{2} \mathrm{Cl}_{2}}$<smiles>CC(C)C[C@H](NC(=O)C(Cc1ccccc1)NC(=O)OCc1ccccc1)B1OC2CC3CC(C)(C2)CC1(C)C3</smiles><smiles>[R]C(=O)N[C@H](Cc1ccccc1)C(=O)N[C@H](CC(C)C)B1O[C@@]2(C)CC(CC(C)(C)C2)C1(C)C</smiles><smiles>[R]C(=O)NC(Cc1ccccc1)C(=O)N[C@H](CC(C)C)B(O)O</smiles>

\section{$R=2$-thienyl, tetrhydrofuranyl, 4-nicotinyl}

Scheme 1. Synthesis of novel analogs 4, 6, and 8 of bortezomib.
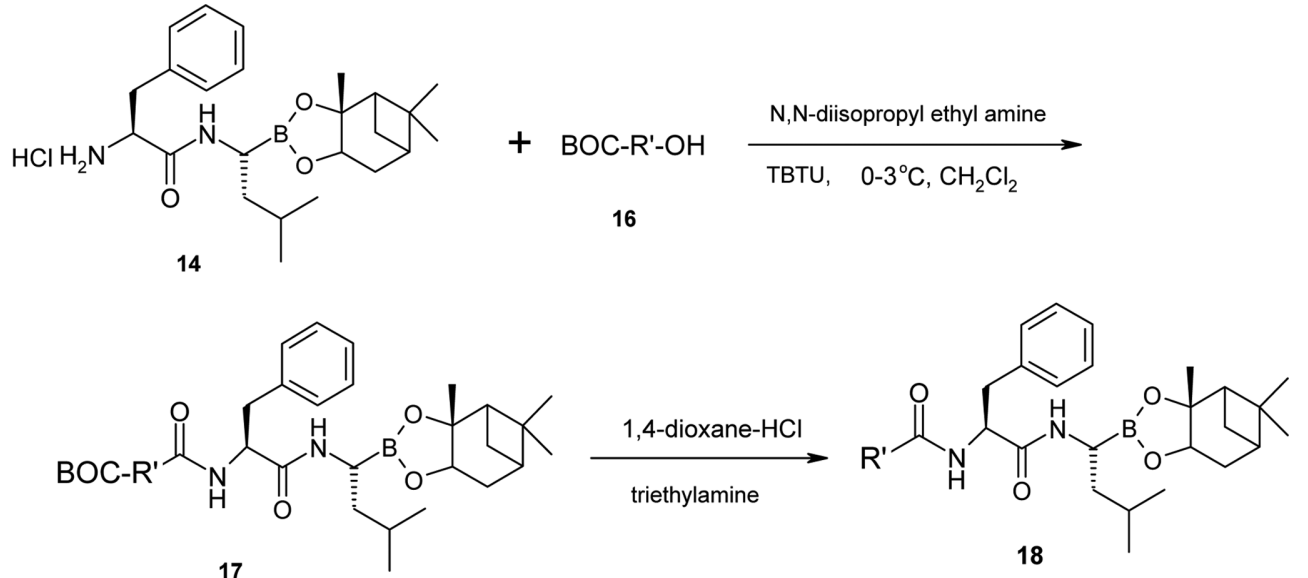

17<smiles>[R]C(=O)N[C@@H](Cc1ccccc1)C(=O)N[C@H](CC(C)C)B(O)O</smiles>

$R^{\prime}=\langle\underset{\substack{N \\ H}}{\longrightarrow}$<smiles>NCCc1c[nH]c2ccccc12</smiles>

Scheme 2. Synthesis of novel analogs $\mathbf{1}$ and $\mathbf{2}$ of bortezomib.

and $\mathrm{PC} 3$ respectively) were treated with bortezomib and $\mathbf{1 , 2}, \mathbf{4}, \mathbf{6}$, and 8 cell viability was measured.

Bortezomib and its analogs 1, 2, 4, 6, and 8 were added to cells and $72 \mathrm{~h}$ later, cell viability was assessed by the thiazolylblue (MTT) assay. All experiments were performed in triplicates. After $72 \mathrm{~h}$ of treatment bortezomib and its analogs potently induced cytotoxicity in cell lines was tested (Fig. 9 and Fig. 10). Analogs 1,2,4,6 and 8 are 


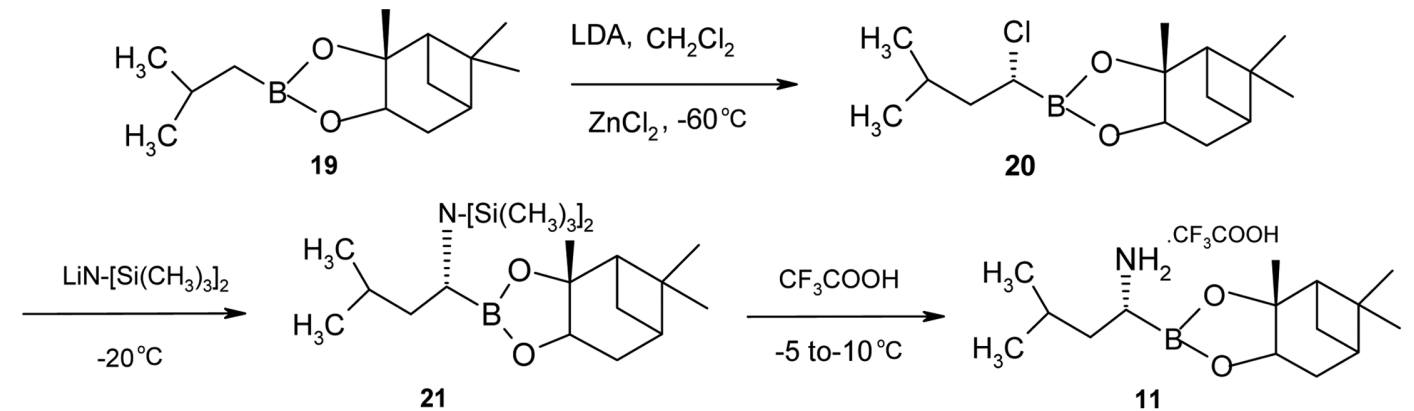

Scheme 3. Synthesis of key intermediate (1R)-(1S,2S,3R,5S)-Pinanediol leucineboronate trifluoroacetate salt (11).

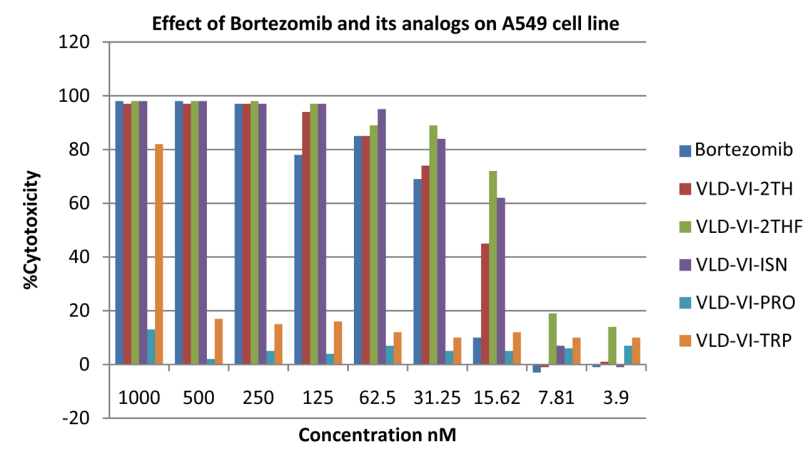

Fig. 9. Cytotoxicity of Bortezomib and its analogs 1, 2, 4, 6, and 8 on A549 Cancer cell line.

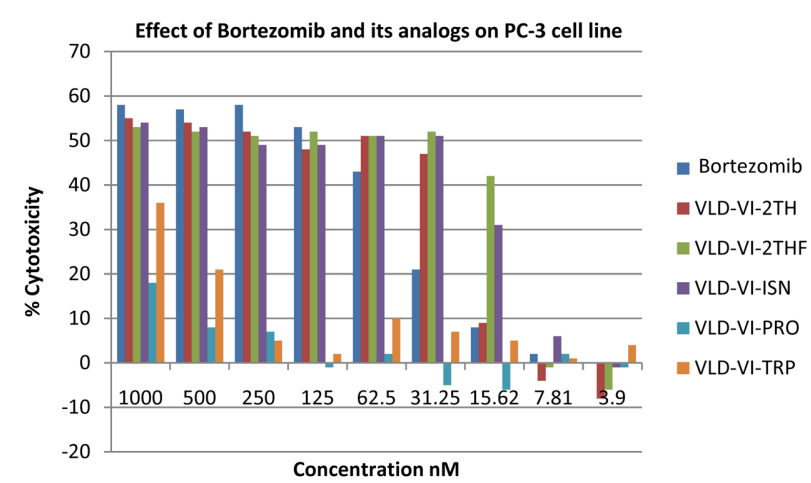

Fig. 10. Cytotoxicity of Bortezomib and its analogs 1, 2, 4, 6, and $\mathbf{8}$ on PC3 Cancer cell line.

Table 2. $\mathrm{IC}_{50}$ values of Bortezomib and its analogs on $\mathrm{A} 549$ cell line (72 Hrs)

\begin{tabular}{ccc}
\hline Entry & $\begin{array}{c}\text { Name of the Drug/Dilutions } \\
(1000-3.9 \mathrm{nM})\end{array}$ & $\begin{array}{c}\mathrm{IC}_{50} \text { Values } \\
(\mathrm{nM})\end{array}$ \\
\hline 1 & Bortezomib & 27.311 \\
2 & Analog 1 & 845.345 \\
3 & Analog 2 & $>1996$ \\
4 & Analog & 14.030 \\
5 & Analog 6 & 18.498 \\
6 & Analog 8 & 12.389 \\
\hline
\end{tabular}

Table 3. $\mathrm{IC}_{50}$ values of Bortezomib and its analogs on $\mathrm{PC} 3$ cell line (72 Hrs)

\begin{tabular}{ccc}
\hline Entry & $\begin{array}{c}\text { Name of the Drug/Dilutions } \\
(1000-3.9 \mathrm{nM})\end{array}$ & $\begin{array}{c}\mathrm{IC}_{50} \text { Values } \\
(\mathrm{nM})\end{array}$ \\
\hline 1 & Bortezomib & 42.039 \\
2 & Analog 1 & $>1996$ \\
3 & Analog 2 & $>1996$ \\
4 & Analog 4 & 26.086 \\
5 & Analog 6 & 37.022 \\
6 & Analog 8 & 21.15 \\
\hline
\end{tabular}

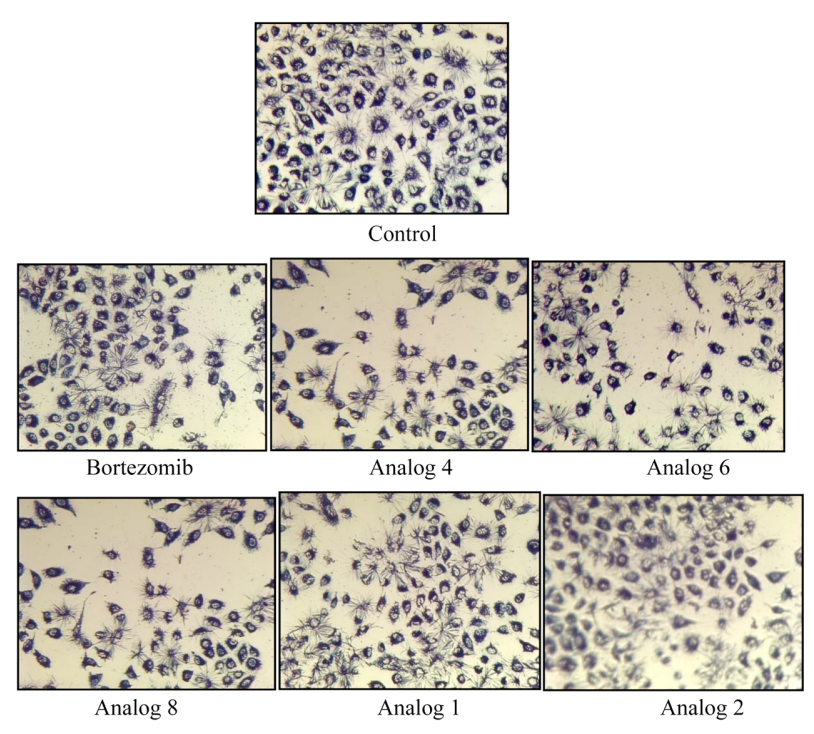

Fig. 11. Pictures showing the Effect of Bortezomib and its analogs on A549 cell line.

designated VLD-VI-TRP, VLD-VI-PRO, VLD-VI-ISN, VLD-VI-2TH and VLD-VI-2THF respectively in Fig. 9 and Fig. 10. The $\mathrm{IC}_{50}$ values of analogs 4, 6, 8 were lower than the bortezomib in A549 Cell line (Table 2) and in PC3 cell line (Table 3), whereas $\mathrm{IC}_{50}$ values of analogs 1 and 2 were higher than the bortezomib.

The effect of bortezomib analogs on A549 and PC3 cell lines are depicted in Fig. 11 and Fig. 12 respectively. 


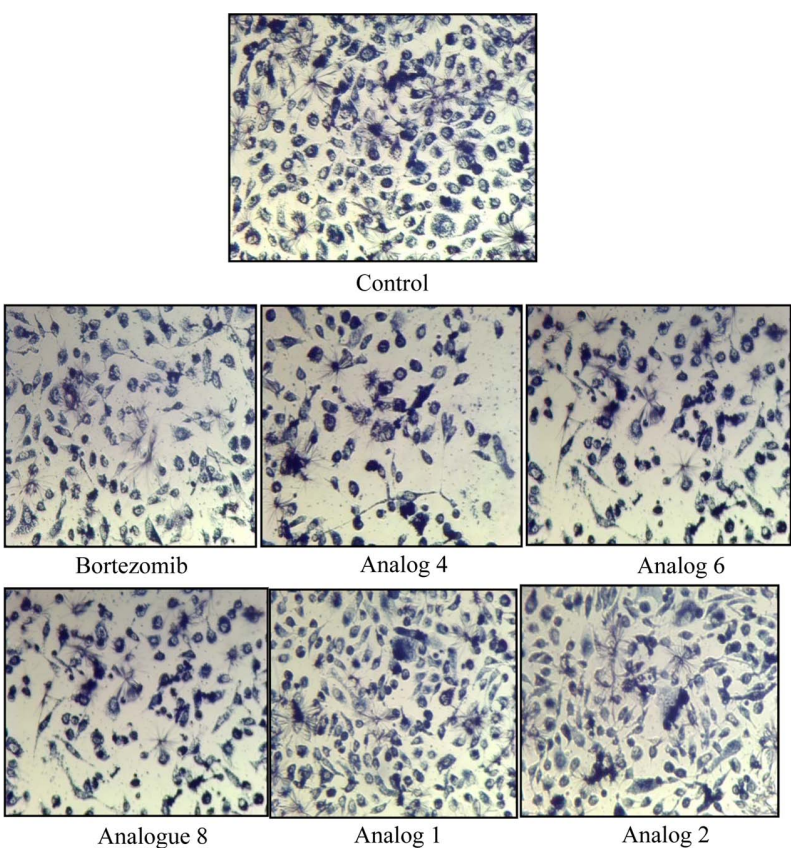

Fig. 12. Pictures showing the Effect of Bortezomib and its analogs on PC3 cell line.

\section{CONCLUSION}

A total of ten novel analogs of bortezomib were designed by substituting the 2-pyrazinyl moiety with various 5 - and 6-membered ring heterocycles. These were subjected to molecular modeling study to estimate the binding affinity with PDB ID 2F16 imported from protein data bank (PDB). The more potent analogs $\mathbf{4 , 6 , 8}$ and the least potent analogs 1 and $\mathbf{2}$ were selected from docking studies to synthesize and evaluate biological activities. A549 (lung cancer) and PC3 (prostate cancer), were employed for cytotoxity studies, and $\mathrm{IC}_{50}$ values were calculated. The results obtained from the activity study revealed that cytotoxicity of borterzomib analogs $4,6,8$ are more than bortezomib, analogs $\mathbf{1}$ and $\mathbf{2}$ didn't show any cytotoxic effect. The results obtained from docking studies are concordant with biological testing results.

\section{EXPERIMENTAL PROCEDURES}

\section{Docking studies}

The protein and ligands for docking were prepared using software Discovery Studio 2.5 C-Docker program. The initial structure of bortezomib was derived from the crystal complex coordinates (PDB ID-2F16). The docking process was carried out by using Discovery Studio CDocker program. A set of ligand conformations were gen- erated using high temperature molecular dynamics with random seed. For each final pose, CHARMm energy and interaction energy were calculated. To evaluate the developed docking procedure, the structure of bortezomib was docked into the binding pocket. As shown in the docking result, the ten analogs designed were docked in same binding site, by the above mentioned docking procedure. The results revealed that out of ten analogs six compounds $3,4,5,6,8$, and 9 are good and in turn 8 is more potent among them. Molecules 7, and $\mathbf{1 0}$ are expected moderate activity and molecule $\mathbf{1}$ and $\mathbf{2}$ are expected to be least active.

\section{Synthesis}

All reactions were monitored by thin layer chromatography and carried out on $0.2 \mathrm{~mm}$ E. Merck silica gel plates (60F-254) using UV light as a visualizing agent. All solvents were obtained from commercial source and freshly distilled before use. Analytical HPLC was performed on a Waters system equipped with a UV detector set at $215 \mathrm{~nm}$. Compounds were dissolved in mobile phase and injected through a $100 \mu \mathrm{L}$ loop. The following gradient system was used as eluent mobile phase A: acetonitrile, water and formic acid in the ratio of 30: 70: $0.1(\mathrm{~V} / \mathrm{V} / \mathrm{V})$ and mobile phase B: acetonitrile, water and formic acid in the ratio of 80:20:0.1 (V/V/V). HPLC retention times $\left(t_{R}\right)$ were obtained, at flow rates of $1.0 \mathrm{ml} / \mathrm{min}$, using the following conditions. Develosil C8 -UG-5 $(150 \times 4.6 \mathrm{~mm})$ column a gradient run up to $55 \mathrm{~min}$. Purity of liquid products was checked by GC on Agilent Technologies Model No: 6890N. Optical rotation of chiral molecules was recorded on Rudolph Research Analyticalpolarimeter, Model: AUTOPOLV. The IR spectral data of all the compounds were recorded on Perkin-Elmer FT-IR spectrometer (MODEL NO: PARAGON-1000) using liquid state as $\mathrm{KBr}$ cell and solid state as $\mathrm{KBr}$ dispersion. The ${ }^{1} \mathrm{H}$ NMR and ${ }^{13} \mathrm{C}$ NMR spectra were recorded on Buker $400-\mathrm{MHz}$ spectrometer. The chemical shifts are reported in $\delta$ parts per million (ppm) relative to TMS. The Mass spectra were recorded onWaters Quattro Micro LC/MS/MS.

\section{Preparation of $(1 R)-(1 S, 2 S, 3 R, 5 S)$-pinanediol leucine} boronate trifluoroacetate salt (11)

(+) Pinanediol-2-methylpropane-1-boronate (19, $60 \mathrm{~g}$, 0.25 moles $)$, tert-butyl methyl ether $(300 \mathrm{~mL})$, and methylene dichloride (112.5 g (84.9 mL), 1.32 moles) were charged into $2 \mathrm{~L}$ four necked round bottomed flask. The reaction mass was cooled to -65 to $-60{ }^{\circ} \mathrm{C}$ using liquid nitrogen-acetone bath. LDA (lithium diisopropylamide) 
solution prepared from diisopropyl- amine $(33.3 \mathrm{~g}, 0.33$ moles), $n$-BuLi 1.6 M solution in hexane $(196.8 \mathrm{~mL}, 0.32$ moles) in tetrahydrofuran was added drop wise to the above reaction mass during 50 min under nitrogen atmosphere. The resulting pale yellow coloured cloudy solution was stirred for 20 min at -60 to $-55^{\circ} \mathrm{C}$. Then $\mathrm{ZnCl}_{2}$ solution (64 $\mathrm{g}, 0.47$ moles) in tetrahydrofuran was added drop wise during $50 \mathrm{~min}$. under nitrogen atmosphere. The reaction mass was allowed to stir for $35 \mathrm{~min}$ at -50 to $-45^{\circ} \mathrm{C}$.

The reaction mass was warmed to $-10{ }^{\circ} \mathrm{C}$ and $10 \%$ sulphuric acid (prepared from $36 \mathrm{~g}$ of conc. Sulphuric acid and $324 \mathrm{~mL}$ of water) was added below $0{ }^{\circ} \mathrm{C}$ during 40 $\min$. Layers were separated and the aq. layer was extracted with tert-butyl methyl ether $(120 \mathrm{~mL})$, and combined organic layer was washed with water followed by brine solution. The organic layer was separated, dried over sodium sulphate and solvent was evaporated under reduced pressure at $45^{\circ} \mathrm{C}$, to yield (+) pinanediol( $1 S$ )-1-chloro-3methylbutane -1-boronate (20) as yellow coloured oil. [70 g, $96.7 \%$, purity: $87 \%$ (GC).]

The above compound was taken to next step without further purification.

Lithium bis(trimethylsilyl)amide (20\% in tetrahydrofuran), $226 \mathrm{~mL}$ ( $46 \mathrm{~g}, 0.27$ moles) was charged into $1 \mathrm{~L}$ four necked round bottomed flask and cooled to -25 to $-20{ }^{\circ} \mathrm{C}$ using liquid nitrogen-acetone bath. A solution of $(+)$ pinanediol(1S)-1-chloro-3-methylbutane-1-boronate (20, $70 \mathrm{~g}, 0.25$ moles $)$ in cyclohexane $(150 \mathrm{~mL})$ was added to the above reaction mass drop wise under nitrogen atmosphere during $60 \mathrm{~min}$. The resulting yellow coloured solution was stirred for $65 \mathrm{~min}$ at -25 to $-20^{\circ} \mathrm{C}$.

Solvent was distilled off at $45^{\circ} \mathrm{C}$ under reduced pressure to attain a cream to yellow coloured suspension. The resulting suspension was triturated with cyclohexane (120 $\mathrm{mL}$ ) and filtered, and the residue was washed with diisopropyl ether $(150 \mathrm{~mL})$. The filtrate obtained contains $(1 R)$ (S)-pinanediol-1-bis(trimethylsilyl)amino-3-methylbutane1-boronate (21), which was taken to next step without product isolation.

Trifluoroacetic acid (77 g, 0.67 moles) and diisopropyl ether $(500 \mathrm{~mL})$ were charged into $2 \mathrm{~L}$ three necked round bottomed flask reaction mass was cooled to $-10{ }^{\circ} \mathrm{C}$ (icesalt bath). The solution of $(1 R)-(S)$-pinanediol-1-bis(trimethylsilyl)amino-3-methylbutane-1-boronate (21) obtained above was added drop wise to the reaction mixture. After completion of addition the reaction mass was stirred for 6$8 \mathrm{~h}$ at below $0{ }^{\circ} \mathrm{C}$. The product was filtered from the reaction massand washed with diisopropyl ether to afford the required product $(1 R)-(1 S, 2 S, 3 R, 5 S)$-pinanediol leucine boronate trifluoroacetate salt(11) as off white coloured solid. (50 g, \% yield: 57.6$)$.

$(\alpha)_{\mathrm{D}}^{25}+9.8^{\circ}\left(\mathrm{c}=1\right.$ in methanol);mp: $125-140^{\circ} \mathrm{C}$; GC: 98.8\%; ${ }^{1} \mathrm{H} \mathrm{NMR}\left(\mathrm{CDCl}_{3}\right): \delta 7.79(\mathrm{~s}, 1 \mathrm{H}), 4.33(\mathrm{dd}, 1 \mathrm{H}, \mathrm{J}=$ $8 \mathrm{~Hz}, 4.2 \mathrm{~Hz}), 2.91$ (t, 1H, J=8Hz), $2.25(\mathrm{~m}, 2 \mathrm{H}), 2.03(\mathrm{t}$, $1 \mathrm{H}, \mathrm{J}=5.2 \mathrm{~Hz}), 1.86-1.9(\mathrm{~m}, 3 \mathrm{H}), 1.77(\mathrm{~m}, 2 \mathrm{H}), 1.6(\mathrm{~m}$, $2 \mathrm{H}), 1.38(\mathrm{~s}, 3 \mathrm{H}), 1.27(\mathrm{~s}, 3 \mathrm{H}), 1.05(\mathrm{~m}, 1 \mathrm{H}), 0.92(\mathrm{dd}, 6 \mathrm{H}$, $\mathrm{J}=6.4 \mathrm{~Hz}, 1.6 \mathrm{~Hz}), 0.8(\mathrm{~s}, 3 \mathrm{H}) ;{ }^{13} \mathrm{C} \mathrm{NMR}\left(\mathrm{CDCl}_{3}\right): \delta 162.4$; $120.93,118.02,115.11,112.20,87.61,78.70,50.99,39.31$, 38.28, 35.46, 34.78, 28.04, 26.93, 24.65, 23.86, 22.06; MS (ESI), $\mathrm{m} / \mathrm{z}=266.28\left(\mathrm{M}+1-\mathrm{CF}_{3} \mathrm{COOH}\right), 210.20 ; \mathrm{IR}$ (KBr): $\mathrm{cm}^{-1} 3046.5(-\mathrm{NH}), 2962.7-2872.0$ (Aliphatic C-H streching), $1678.5\left(\mathrm{C}=\mathrm{O}, \mathrm{CF}_{3} \mathrm{COOH}\right), 1420.5-1391.9$ (Aliphatic $\mathrm{C}-\mathrm{H}$ bending), 1202.8 (C-N bending).

Preparation of $(1 S, 2 S, 3 R, 5 S)$-pinanediol- $\beta$-(1-phenyl)-L-alanine-L-leucine boronate $\mathrm{HCl}(14)$

$(1 R)-(1 S, 2 S, 3 R, 5 S)$-Pinanediol leucine boronate trifluoroacetate salt (11, $50 \mathrm{~g}, 0.13$ moles), BOC-L-phenylalanine (12, $35 \mathrm{~g}, 0.13$ moles), TBTU ( $48.16 \mathrm{~g}, 0.150$ moles) and methylene chloride $(760 \mathrm{~mL})$ were charged into in $3 \mathrm{~L} 4$ necked round bottomed flask at room temperature under nitrogen atmosphere and stirred for $5 \mathrm{~min}$. Resulting off white coloured suspension was cooled to $-2{ }^{\circ} \mathrm{C}$ using icesalt bath. N,N-diisopropylethylamine ( $52.45 \mathrm{~g}, 0.41$ moles) was added drop wise to the above reaction mass, during 20-30 $\mathrm{min}$. The reaction mass was then stirred for $35 \mathrm{~min}$ at -2 to $0{ }^{\circ} \mathrm{C}$ for $35 \mathrm{~min}$. TLC was Checked for reaction completion, using mobile phase: Toluene: ethyl acetate (1:1), detection: $\mathrm{UV}$ at $254 \mathrm{~nm}$; and $0.75 \%$ aq. potassium permanganate solution.

The solvent was distilled off at $40-45^{\circ} \mathrm{C}$ under reduced pressure to obtain an oily product. The resulting crude product was dissolved in ethyl acetate washed with water $(2 \times 300 \mathrm{~mL}), 1 \%$ aq. $\mathrm{H}_{3} \mathrm{PO}_{4}$ solution $(390 \mathrm{~mL}), 2 \%$ aq. $\mathrm{K}_{2} \mathrm{CO}_{3}$ solution $(390 \mathrm{~mL})$ followed by $10 \%$ aq. $\mathrm{NaCl}$ solution $(350 \mathrm{~mL})$. Organic layer was separated, dried over sodium sulphate and the solvent was evaporated under reduced pressure at $45^{\circ} \mathrm{C}$ to afford $(1 S, 2 S, 3 R, 5 S)$-pinanediol-NBOC- $\beta$-(1-phenyl)-L-alanine-L-leucineboronate (13) as white coloured foamy solid (67.0 g (Yield: $98.5 \%)$. The compound was taken to next step without further purification.

$(1 S, 2 S, 3 R, 5 S)$-Pinanediol-N-BOC- $\beta$-(1-phenyl)-L-alanine-L-leucineboronate $(\mathbf{1 3}, 67 \mathrm{~g}, 0.13$ moles) was dissolved in ethyl acetate $(200 \mathrm{~mL})$ and cooled to 10 to $15^{\circ} \mathrm{C}$. Then EtOAc- $\mathrm{HCl}$ solution $(830 \mathrm{~mL}$, assay: $11.5 \% \mathrm{w} / \mathrm{v}$; 2.61 moles) was added to the reaction mass and stirred for $4 \mathrm{~h}$. TLC was checked for completionof reaction. The reaction mass was concentrated under reduced pressure at 
$40-45^{\circ} \mathrm{C}$ to yield white coloured suspension. To the resulting suspension was added $450 \mathrm{~mL}$ of fresh ethyl acetate, stirred for $2 \mathrm{~h}$ at room temperature and filtered to afford (1S,2S,3R,5S)-pinanediol- $\beta$-(1-phenyl)-L-alanine-L-leucineboronate $\mathrm{HCl}(\mathbf{1 4})$ as white crystalline solid $(70 \mathrm{~g} ; \%$ yield: 79.84$) ;(\alpha)_{\mathrm{D}}{ }^{25}+8.3$ (c=1 in methanol); mp: $200-205$ ${ }^{\circ} \mathrm{C}$; purity $95.6 \%$ (HPLC); ${ }^{1} \mathrm{H} \mathrm{NMR}\left(\mathrm{CDCl}_{3}\right): \delta 8.23$ (br s, 2H), 7.71 (brs, $1 \mathrm{H}), 7.24-7.35(\mathrm{~m}, 5 \mathrm{H}), 4.67(\mathrm{~m}, 1 \mathrm{H}), 4.22$ $(\mathrm{dd}, 1 \mathrm{H}, \mathrm{J}=7.6 \mathrm{~Hz}, 4.2 \mathrm{~Hz}), 3.29-3.42(\mathrm{~m}, 2 \mathrm{H}), 2.90(\mathrm{t}, 1 \mathrm{H}$, $\mathrm{J}=5.3 \mathrm{~Hz}), 2.27(\mathrm{~m}, 2 \mathrm{H}), 2.11(\mathrm{~m}, 2 \mathrm{H}), 2.02(\mathrm{t}, 1 \mathrm{H}, \mathrm{J}=5.2 \mathrm{~Hz})$, 1.77-1.82 (m, 2H), $1.46(\mathrm{~m}, 2 \mathrm{H}), 1.33(\mathrm{~s}, 3 \mathrm{H}), 1.26(\mathrm{~s}, 3 \mathrm{H})$, $0.84(\mathrm{~m}, 6 \mathrm{H}), 0.8(\mathrm{~s}, 3 \mathrm{H}) ;{ }^{13} \mathrm{C} \mathrm{NMR}\left(\mathrm{CDCl}_{3}\right): \delta 168.21$, 134.05, 129.83, 128.64, 127.26, 85.92, 77.47, 53.46, 51.19, $39.28,38.03,36.98,35.35,28.41,26.99,26.23,24.77$, 23.94, 23.06, 21.56; MS (ESI), m/z=447.11 (M-1), 411.13, 341.06; IR (KBr): cm ${ }^{-1} 3393.9$ (-NH), 2961.9-2868.4 (Aliphatic C-H stretching), $1665.6(\mathrm{C}=\mathrm{O}), 1605.2$ (Amide-II), 1566.0 (Aromatic $\mathrm{C}=\mathrm{C}$ ), 1233.0 (C-N bending).

\section{Synthesis of novel bortezomib analogs 4,6 , and 8}

For the synthesis of bortezomib analogs $4,6,8$ the corresponding carboxylic acids 4-pyridinecarboxlic acid, thiophene-2-carboxylic acid, and tetrahydrofuran-2-carboxylic acid, were employed as substrates to couple with compound 14.

\section{General procedure for the synthesis of compounds}

\section{4, 6, and 8}

$(1 S, 2 S, 3 R, 5 S)$-Pinanediol- $\beta$-(1-phenyl)-L-alanine-Lleucineboronate $\mathrm{HCl}(\mathbf{1 4}, 1$ mole equivalent), the corresponding carboxylic acid (1.1 mole equivalents), TBTU (1.1 mole equivalents) were charged into 3 necked round bottomed flask along with methylene chloride. Reaction mass was cooled to $0-3{ }^{\circ} \mathrm{C}$, then $\mathrm{N}$, N-diisopropylethylamine (3.5 mole equivalents) was added drop wise to the above reaction mass under nitrogen atmosphere. The reaction mass stirred for $1 \mathrm{~h}$ at $15-20{ }^{\circ} \mathrm{C}$ for completion of reaction. The reaction completion was essentially monitored by TLC.

Solvent from the reaction mass was distilled off at 40$45{ }^{\circ} \mathrm{C}$ under reduced pressure to obtain an oily liquid. The resulting product was dissolved in ethyl acetate washed with water, $1 \%$ aq. $\mathrm{H}_{3} \mathrm{PO}_{4}$ solution, $2 \%$ aq. $\mathrm{K}_{2} \mathrm{CO}_{3}$ solution, followed by $10 \%$ aq. $\mathrm{NaCl}$ solution. The organic layer was separated, dried over sodium sulphate and the solvent was evaporated under reduced pressure at $45^{\circ} \mathrm{C}$ to afford required dipeptidyl pinanediol boronate compound (15) aspale yellow coloured residue.

The compound obtained above is dissolved in methanol, then was added isobutyl boronic acid (1.84 mole equivalents) in heptane. $1 \mathrm{~N}$ aq. hydrochloric acid was added drop wise to the reaction mass and stirred for $16 \mathrm{~h}$ at room temperature. Layers were separated, aq. layer was concentrated to attain white coloured suspension. The resulting suspension was dissolved in $2 \mathrm{~N}$ aq. sodium hydroxide solution, and washed with methylene chloride. Aq. layer was separated, $\mathrm{pH}$ was adjusted to $6 \pm 0.5$ with $1 \mathrm{~N}$ aq. hydrochloric acid and the resulting precipitate was extracted into methylene chloride. Solvent was evaporated under vacuum to afford required product as white coloured foam. The foam was crystallized from suitable solvent to get pure product.

N-(4-Nicotincarbonyl-L-phenylalanine-L-leucineboronic acid (4): Crystallized from EtOAc; Yield: 56\%; mp: $124.7{ }^{\circ} \mathrm{C}$; purity (HPLC): $99.07 \% ;{ }^{1} \mathrm{H}$ NMR (DMSO- $d_{6}$ ): $\delta 9.06(\mathrm{~d}, 1 \mathrm{H}, \mathrm{J}=8.4 \mathrm{~Hz}), 8.9(\mathrm{~d}, 2 \mathrm{H}, \mathrm{J}=8.4 \mathrm{~Hz}), 8.7-8.66$ (dd, $2 \mathrm{H}, \mathrm{J}=10.4 \mathrm{~Hz}, \mathrm{~J}=4.8 \mathrm{~Hz}), 7.3-7.55(\mathrm{~m}, 5 \mathrm{H}), 4.83$ (m, 1H), 3.3-3.5 (m, 2H), 2.6 (brs, $1 \mathrm{H}), 1.54(\mathrm{~m}, 2 \mathrm{H})$, 1.35(m, 2H), $1.15(\mathrm{~m}, 1 \mathrm{H}), 0.75-0.8(\mathrm{~m}, 6 \mathrm{H}) ;{ }^{13} \mathrm{C} \mathrm{NMR}$ (DMSO-d $): \delta 173.3 ; 170.4,164.6,150.0,141.0,140.7$, $138.4,137.4,129.2,128.0,126.2,121.3,54.8,52.5$, 36.9, 24.8, 23.2, 22.5, 22.1; MS (ESI), $\mathrm{m} / \mathrm{z}=383.23$ (M+ ion), 382.22 (M-1peak), $364.22\left(\mathrm{M}-1-\mathrm{H}_{2} \mathrm{O}\right)$; IR (KBr): $\mathrm{cm}^{-1} 3430.3,3307.5,3066.2,2950.3,1633.1,1532.8,1398.8$, 1284.4, 1209.8 .

N-(2-Thiophene)carbonyl-L-phenylalanine-L-leucine boronic acid (6): Crystallized from EtOAc: heptane (1:9); Yield: $35 \%$; mp: $130.4{ }^{\circ} \mathrm{C}$; purity (HPLC): $98.64 \%$; ${ }^{1} \mathrm{H}$ NMR (DMSO- $\left.d_{6}\right): \delta 8.82$ (brs, $\left.1 \mathrm{H}\right), 8.72(\mathrm{~d}, 1 \mathrm{H}, \mathrm{J}=8.4 \mathrm{~Hz}$ ), $7.82(\mathrm{~d}, 1 \mathrm{H}, \mathrm{J}=2.8 \mathrm{~Hz}), 7.7$ (d, 1H, J=4.8Hz), 7.54 (m, IH), 7.1-7.31 (m, 6H), $4.8(\mathrm{~m}, 1 \mathrm{H}), 2.9-3.1(\mathrm{~m}, 2 \mathrm{H}), 2.6$ (brs, $1 \mathrm{H}), 1.55(\mathrm{t}, 1 \mathrm{H}, \mathrm{J}=6.4 \mathrm{~Hz}), 1.25(\mathrm{~m}, 2 \mathrm{H}), 0.75-0.83(\mathrm{~m}$, $7 \mathrm{H}) ;{ }^{13} \mathrm{CNMR}$ (DMSO- $\left.d_{6}\right): \delta 173.5,170.6,161,150.0,139.1$, 137.5, 131.0, 129.2, 128.7, 127.8, 126.4, 54.6, 43.0, 37.1, 25.0, 23.0, 22.5; MS (ESI), $\mathrm{m} / \mathrm{z}=388.21(\mathrm{M}+$ ion), 387.21 (M-1peak), 369.20 (M-1- $\left.\mathrm{H}_{2} \mathrm{O}\right)$; IR ( $\left.\mathrm{KBr}\right): \mathrm{cm}^{-1} 3295.4$, 3089.3, 2952.4, 1628.2, 1537.7, 1384.1, 1281.5, 1200.6.

N-(2-Tetrahydrofuran)carbonyl-L-phenylalanineL-leucineboronic acid (8): Crystallized from EtOAc: heptane (1:9); Yield: $43 \%$; mp: $69.9^{\circ} \mathrm{C}$; purity (HPLC): 98.89\%; ${ }^{1} \mathrm{H}$ NMR (DMSO- $\left.d_{6}\right): \delta 7.19-7.28(\mathrm{~m}, 5 \mathrm{H}), 6.9$ $(\mathrm{m}, 1 \mathrm{H}), 4.83(\mathrm{~m}, 1 \mathrm{H}), 4.7(\mathrm{~m}, 1 \mathrm{H}), 4.2$ (brs, $1 \mathrm{H}), 3.6-3.8$ $(\mathrm{m}, 2 \mathrm{H}), 3.0-3.23(\mathrm{~m}, 2 \mathrm{H}), 2.2(\mathrm{~m}, 1 \mathrm{H}), 1.80(\mathrm{~m}, 4 \mathrm{H}), 1.5$ $(\mathrm{m}, 2 \mathrm{H}), 1.25(\mathrm{~m}, 2 \mathrm{H}), 0.86(\mathrm{~m}, 7 \mathrm{H}) ;{ }^{13} \mathrm{C}$ NMR (DMSO$\left.d_{6}\right): \delta 174.7173 .5,136.0,129.2,128.5,127.0,78.1,69.3$, 52.2, 39.9, 37.6, 31.8, 30.0, 28.9,25.8, 22.6, 14.0; MS (ESI), $\mathrm{m} / \mathrm{z}=376.23(\mathrm{M}+$ ion), 375.22 (M-1 peak), 357.22 (M-1$\mathrm{H}_{2} \mathrm{O}$ ); IR (KBr): $\mathrm{cm}^{-1} 3404.1,3065.2,2953.4,1654.3$, 1521.0, 1394.4, 1238.6, 1201.1, 1072.4. 


\section{Synthesis of analogues 1and 2}

Boc-L-tryptophan and Boc-L-proline were employed as substrates to prepare bortezomib analogs 1 and 2 respectively.

\section{General procedure for the synthesis of analogues 1 and 2}

$(1 S, 2 S, 3 R, 5 S)$-Pinanediol- $\beta$-(1-phenyl)-L-alanine-Lleucineboronate $\mathrm{HCl}(\mathbf{1 4}, 1$ mole equivalent), the corresponding Boc-N-protected amino acid (16, 1.1 mole equivalents), TBTU (1.1 mole equivalents) were charged into three necked round bottomed flask along with methylene chloride. The reaction mass was cooled to $0-5{ }^{\circ} \mathrm{C}$, then $\mathrm{N}, \mathrm{N}$-diisopropylethylamine (3.5 mole equivalents) was added drop wise to the reaction mass under nitrogen atmosphere. The reaction mass was stirred for $1 \mathrm{~h}$ at $15-20^{\circ} \mathrm{C}$ for completion of reaction (TLC).

Solvent was distilled off at $40-45^{\circ} \mathrm{C}$ under reduced pressure to obtain pale brown coloured oily liquid. The resulting crude was dissolved in ethyl acetate washed with successively water, $1 \%$ aq. $\mathrm{H}_{3} \mathrm{PO}_{4}$ solution, $2 \%$ aq. $\mathrm{K}_{2} \mathrm{CO}_{3}$ solution, followed by $10 \%$ aq. $\mathrm{NaCl}$ solution. The organic layer was separated dried over sodium sulphate and the solvent was evaporated under reduced pressure at $45^{\circ} \mathrm{C}$ to afford required dipeptidyl pinanediol boronate compound (17) aspale yellow coloured residue. The compound obtained was dissolved in ethyl acetate, then 1,4-dioxane$\mathrm{HCl}$ (5 mole equivalents) was added, reaction mass was stirred overnight at room temperature. Product was filtered from the reaction mass, and washed with ethyl acetate to yield a cream coloured solid (18). The compound was suspended in ethylacetate and neutralized with triethylamine and filtered. The filtrate was evaporated under reduced pressure at $45^{\circ} \mathrm{C}$ to get white coloured foamy mass.

The compound (18) obtained above was dissolved in methanol, then was added isobutyl- boronic acid (1.84 mole equivalents) in heptane. $1 \mathrm{~N}$ aq. hydrochloric acid was added drop wise to the reaction mass and stirred for $16 \mathrm{~h}$ at room temperature. Layers were separated, aq. layer was concentrated to obtain white coloured suspension. The resulting suspension was dissolved in $2 \mathrm{~N}$ aq. sodium hydroxide solution, and washed with methylene chloride. Aq. layer was separated, $\mathrm{pH}$ was adjusted to $6 \pm 0.5$ with $1 \mathrm{~N}$ aq. hydrochloric acid and the resulting precipitate was extracted into methylene chloride. Solvent was evaporated under vacuum to afford the required product as white coloured foam. The foam was crystallized from suitable solvent to get pure product.
$\mathrm{N}$-(Tryptophan)carbonyl-L-phenylalanine-L-leucineboronic acid (1): Crystallized from heptane; Yield: 52\%; mp: $139.4{ }^{\circ} \mathrm{C}$; purity (HPLC): $94.82 \%$; ${ }^{1} \mathrm{H}$ NMR (DMSO- $\left.d_{6}\right): \delta 7.3-7.5(\mathrm{~m}, 4 \mathrm{H}), 7.1-7.3(\mathrm{~m}, 5 \mathrm{H}), 6.9(\mathrm{~s}$, 1H), 6.6 (brs, 1H), 6.3 (s, 1H), 5.3 (d, 2H, J=7.6 Hz), 4.8 $(\mathrm{m}, 1 \mathrm{H}), 4.6(\mathrm{~m}, 1 \mathrm{H}), 3.3-3.5(\mathrm{~m}, 2 \mathrm{H}), 2.2(\mathrm{~m}, 2 \mathrm{H}), 1.70$ (m, 1H), 1.35(m, 2H), 0.75-0.80 (m, 7H); ${ }^{13} \mathrm{C}$ NMR (DMSO- $d_{6}$ ): $\delta 176.5,172.8 .6,166.7,155.6,150.0,148.8$, $141.5,139.1,137.5,133.0,129.2,128.7,127.8,126.4$, 54.6, 43.0, 37.1, 25.0, 23.0, 22.5; MS m/z: 446.33 (M$\left.\mathrm{H}_{2} \mathrm{O}\right), 445.32\left(\mathrm{M}-\mathrm{H}_{2} \mathrm{O}-1\right)$; IR (KBr): $\mathrm{cm}^{-1} 3404.3,3350.6$, 3076.4, 2952.0, 1636.4, 1515.8, 1363.8, 1231.2.

N-(2-Prolin)carbonyl-L-phenylalanine-L-leucineboronic acid (2): Crystallized from EtOAc; Yield: 39\%; mp: $95.7^{\circ} \mathrm{C}$; purity (HPLC): $99.35 \%,{ }^{1} \mathrm{H}$ NMR (DMSO- $d_{6}$ ): $\delta$ 7.60 (brs, $1 \mathrm{H}), 7.16-7.20(\mathrm{~m}, 5 \mathrm{H}), 4.65(\mathrm{~m}, 1 \mathrm{H}), 4.5$ (m, 1H) 3.05 (m, 2H), 2.75-2.9 (m, 2H), 2.7 (brs, $1 \mathrm{H}), 2.55$ (brs, $1 \mathrm{H}), 1.80(\mathrm{~m}, 1 \mathrm{H}), 1.27-1.44(\mathrm{~m}, 6 \mathrm{H}), 0.80(\mathrm{~m}, 7 \mathrm{H})$; ${ }^{13} \mathrm{C}$ NMR (DMSO- $d_{6}$ ): $\delta 174.7,173.5,138.0,129.8,128.5$, 126.6, 77.1, 70.3, 57.2, 40.2, 37.6, 34.8, 30.8, 27.9,24.8, 22.8, 13.8; MS m/z: 375.26 (M+ ion), 374.25 (M-1peak), 356.23 (M-1- $\mathrm{H}_{2} \mathrm{O}$ ); IR (KBr): $\mathrm{cm}^{-1}$ 3426.0, 3300.3, 3114.4, 2948.6, 1627.1, 1537.7, 1384.3, 1271.2, 1247.8.

\section{Biological activity}

The MTT kit received from promega was used. A 549 (lung cell line) and PC3 (prostate cancer cell line) were obtained from American type culture collection and maintained in F12K medium (Hi-media) supplemented with $10 \%$ fetal bovine serum (SFC bioscience), $200 \mathrm{mM} \mathrm{L-}$ glutamine and 1000 units $/ \mathrm{mL}$ penicillin/streptomycin (10 $\mathrm{mg} / \mathrm{mL}$ ) [Hi-media] in a humidified atmosphere of $5 \%$ $\mathrm{CO}_{2}$ and $95 \%$ air.

Bortezomib and its analogs $1,2,4,6$, and 8 were dissolved in DMSO as a $10 \mathrm{mM}$ stock solution and diluted to required concentration with PBS (1X) (Phosphate Buffer Saline).

Cytotoxicity of Bortezomib and its analogs 1, 2, 4, 6, and 8: Cytotoxicity analysis was carried out by using 3(4,5-dimethylthiazol-2-yl)2,5-diphenyl- tetrazolium bromide (MTT) dye reduction assay. Exponential growing cells were exposed to bortezomib and its analogs $1,2,4,6$, and $\mathbf{8}$ for the indicated time. The drug-induced cytotoxicity was assessed by the MTT assay. Lung cancer cell line and prostate cancer cell line (A549 and PC3 respectively) were treated with bortezomib and its analogs $1,2,4,6,8$ and cell viability was measured.

PC 3 and A549 cells were seeded in 96 well plate the day before chemical treatment of concentration of $4 \times 10^{3}$ cells/ 
well and $1.25 \times 10^{4}$ cells/well respectively. The test samples were added to cells and $72 \mathrm{~h}$ later the cell viability was assessed by the thiazolyl blue (MTT) assay. All experiments were performed in triplicates. After $72 \mathrm{~h}$ of treatment the test compounds induced cytotoxicity of cell lines tested. The $\mathrm{IC}_{50}$ values of analogs $\mathbf{4 , 6 , 8}$ were lower than the bortezomib in A549 Cell line and in PC3 cell line, whereas the $\mathrm{IC}_{50}$ values of analogs $\mathbf{1}$ and $\mathbf{2}$ were higher than the bortezomib.

Acknowledgement. The authors thank the management of Natco Pharma Ltd. for supporting this work. The technical service from the analytical division and cell biology division of Natco Research Centre is gratefully acknowledged.

\section{REFERENCES}

1. Goldberg, A. L. Nature. 2003, 426, 895.

2. Voges, D.; Zwickl, P.; Baumeister, W. Annu. Rev. Biochem. 1999, 68, 1015.

3. Julian Adams.; Yu-Ting Ma.; Ross Stein.; Matthew Baevsky.; Louis Grenier.; Louis Plamondon. U.S. Patent 5780454, 1998.

4. Orlowski, L. Z.; Zeger, E. L. Expert Opin. Invest. Drugs
2006, $15,117$.

5. Dorsey, B. D.; Iqubal, M.; Chatterjee, S.; Menta, E.; Bernardini, R.; Bernareggi, A.; Cassar, P.G.; D’Ansmo, G.; Ferretti, E.; DeMunari, S.; Oliva, A.; Pezzoni, G.; Allievi, C.; Strepponi, I.; Ruggeri, B.; Atori, M.A.; Williams, M.; Mallamo, J.P. J. Med. Chem. 2008, 51, 1068.

6. Yongqiang Zhu.; Xin Zhao.; Xinrong Zhu.; Gangwu, Yuejie Li.; Yuheng Ma.; Yunxia Yuan.; Jie Yang.; Yang Hu.; Li Ai.; Qingzhi Gao. J. Med. Chem. 2009, 52, 4192.

7. Yongqiang Zhu.; Xinrong Zhu.; Gang Wu.; Yuheng Ma.; Yuejie Li.; Xin Zhao.; Yunxia Yuan.; Jie Yang.; Sen Yu.; Feng Shao.; Rutalo Li.; Yanrong Ke.; Aijun Lu.; Zhenming Liu.; Liangren Zhang. J. Med. Chem. 2010, 53, 1990.

8. Yongqiang Zhu.; Shuyang Yao.; Bo Xu, Zemei Ge.; Jingrong Cui.; Tieming Cheng. Bioorg. Med. Chem. Lett. 2009, 6851.

9. Lowe, J.; Stock, D.; Jap, B.; Baumeister, W.; Huber, R. Science 1995, 268, 533.

10. Groll, M.; Ditzal, L.; Lowe, J.; Stock, D.; Bochtler, M. B.; Huber, R. Nature 1997, 386, 463.

11. Groll, M.; Huber, R.; Potts, B. C. J. Am. Chem. Soc. 2006, 128, 5136.

12. Groll, M.; Brekers, C. R.; Ploegh, H. L.; Ovaa, H. Structure 2006, 14, 451.

13. Fraser Pickersgill, John E. Bishop etal. U.S. Patent 0240047A1, 2005. 